University of Nebraska - Lincoln

DigitalCommons@University of Nebraska - Lincoln

Agronomy \& Horticulture -- Faculty Publications

Agronomy and Horticulture Department

8-12-1949

\title{
Quantitative Study of Root Systems in Different Soil Types
}

\author{
J. E. Weaver \\ University of Nebraska-Lincoln
}

R. W. Darland

Follow this and additional works at: https://digitalcommons.unl.edu/agronomyfacpub

Part of the Plant Sciences Commons

Weaver, J. E. and Darland, R. W., "Quantitative Study of Root Systems in Different Soil Types" (1949). Agronomy \& Horticulture -- Faculty Publications. 498.

https://digitalcommons.unl.edu/agronomyfacpub/498

This Article is brought to you for free and open access by the Agronomy and Horticulture Department at DigitalCommons@University of Nebraska - Lincoln. It has been accepted for inclusion in Agronomy \& Horticulture -Faculty Publications by an authorized administrator of DigitalCommons@University of Nebraska - Lincoln. 
face to maximum depth of penetration may be taken, separated from the soil without injury to the root or displacement of individual roots from their natural position, and examined in the laboratory in relation to the various horizons of the soil profile. The method, applied to range grasses, consists in obtaining monoliths of soil $12 \mathrm{in}$. wide and $3 \mathrm{in}$. thick to a depth, varying with root extent, of 3-6 ft.

A trench about $3 \mathrm{ft}$ wide and 4-5 $\mathrm{ft}$ long is dug in a site where there is normal development of vegetation. The depth is usually 4-6 ft. Beneath the particular sample of grass, previously selected and left undisturbed in the side wall, the wall of the trench is made smooth and vertical, as shown by a plumb line. A long shallow wooden box, $12 \mathrm{in}$. wide and $3 \mathrm{in}$. deep (inside dimensions), without a top and lacking one end, is employed. It is placed on end, with the closed end downward. The open top is placed against the vertical trench wall, the upper end of the box just reaching the soil surface. An impression of the sides and lower end of the box is made on the vertical wall of the trench by tapping the bottom of the box vigorously with a 4-lb sledge. The box is then removed and the soil solumn marked out with butchers' knives having rigid blades. The soil on the sides and below these marks is removed by means of knives and spades until the monolith protrudês from the trench wall, its sides and bottom extending outward at least 3 in. The box is then fitted tightly over the monolith and the buttom and lower end of the box are braced to hold the soil column in place. Finally, the soil on the inner, attached face of the monolith is cut away by working inward with knives and spades from each side. The soil is not cut close to the top of the box, but a $\mathrm{V}$-shaped ridge of soil is left protruding throughout its length. This is a part of the sample when the braces are removed and the monolith is lifted out of the trench. The entire monolith is transported to the laboratory, where a description of the profile as regards soil texture, structure, consistence, $\mathrm{pH}$, etc. is made. Only then is the monolith reduced to exactly $3 \mathrm{in}$. in thickness.

The soil is removed from the box by a process of repeated soaking, often for several days, and gentle washing, mostly under water, even when it is extremely compact or contains a claypan. A flaring rose nozzle attached to a garden hose is employed. During this process one may study the intimate relations of soil and roots. Roots are unharmed and in their natural position in the water after the soil has been washed away.

The root system is transferred to a large smooth painted board. The board is kept wet and tilted while the roots are finally washed free of any remaining soil. Excess water is then removed by large blotters and the damp root system is transferred to a mounting board covered with cloth of black felt. This is done by placing the mounting board, face downward, over the root system, holding the two boards tightly together, and inverting them. The painted board is then removed. The root system is lighted for photographing by electroflash units. It may then be dried and preserved indefinitely or cut into sections according to depth in feet or according to 


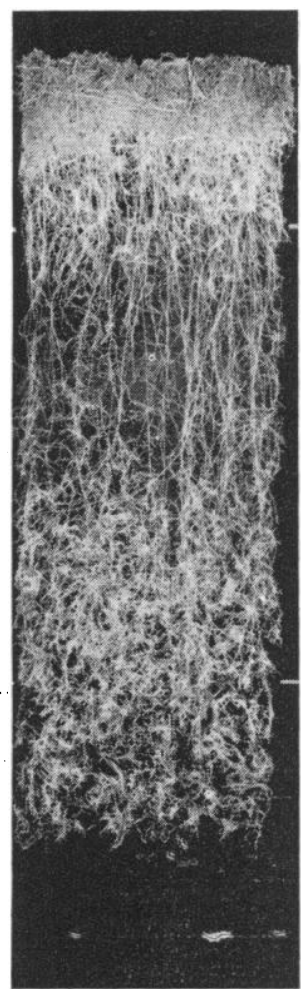

Fig. 1. Portion of a root system of western wheat griss (Agropyron smithii Rydb.) 12 in. wide and 36 in. deep. The bottoms of the $A$ and $B$ horizons are marked by white lines. Oniy a small portion of the roots in the $C$ horizon is shown.

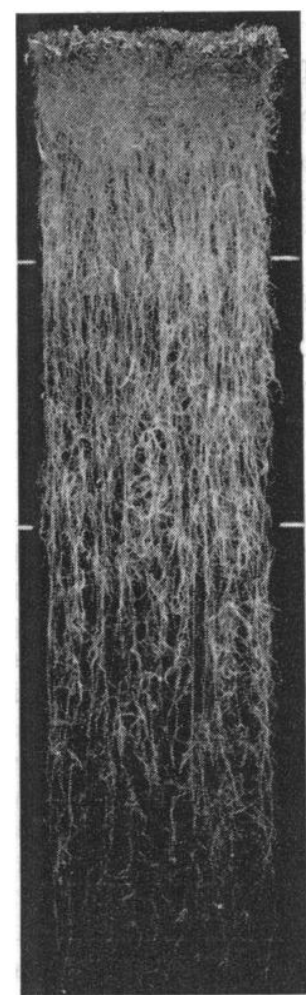

Frg. 2. Upper $4 \mathrm{ft}$ of roots of buffalo grass Buchlö̈ dactyloides (Nutt.) Engelm. Upper lines mark the depth of a 12-in. fll which gradually buried the former topsoll ( $A_{1-1}$ horizon). 14 in. thick. Note excellent root development in these layers.

depth of the soil horizons it occupied. The roots are then oven-dried and weighed.

The root system in Fig. 1 was taken from Butler silt loam soil 28 in. deep, overlying deep, friable, silty clay loam parent material. The $\boldsymbol{A}$ horizon, which is only 7.5 in. thick, contained $67 \%$ of the roots by weight. Roots were poorly branched in all but the lower part of the claypan or $B$ horizon. Most of the branching occurred in the $C$ horizon of less compacted, friable silty clay loam. Roots in the 13 in. below the point of heavy branching weighed $36 \%$ more than the 13 in. of poorly branched roots above. The root system in Fig. 2 was taken from Wabash silt loam in a valley between two loess hills. Although the grass is normally only 4-5-in. tall, the roots are 5-6 ft deep.

Descriptions have been made of the profiles of 16 soil types, from which 11 species of grasses were taken in a total of 33 monoliths in 1948.1 The depth, density, and weight-distribution of roots of the same species in dif-

1 Profile descriptions were male hy Mr. James Thorp. Principal Soll Correlator, Grent Plains States Division of Soll Survey, U. S. Dept. of Agriculture.

ferent soil types and of different species in the same soil type have been ascertained. Quantitative data on root distribution in the several soil horizons have also been obtained. The effect of buried profiles on root habit has been examined, as have modifications resulting from the loss of one or more soil horizons by erosion. A detailed account of the work is in press.

\section{References}

1. WeAver, J. E. The ecological relations of roots. (Publ. 286). Washington, D. C. : Carnegie Institution, 1919. MeGrnw-Hill. 1926. 